\title{
Problems of Differential Diagnosis in Melanoma Arising from Blue Naevus
}

\author{
R. ANDREI ${ }^{1}$, SABINA ZURAC ${ }^{1,2}$, C. SOCOLIUC ${ }^{1,2}$, P. MANDISODZA $^{3}$, FLORICA STANICEANU ${ }^{1,2}$ \\ 1“Colentina” University Hospital, Department of Pathology \\ ${ }^{2}$ University of Medicine and Pharmacy, Department of Pathology \\ 3"Colentina" University Hospital, Department of Surgery, Bucharest, Romania
}

Melanoma arising from blue naevus is an exceedingly rare variant of melanoma. Most of the cases are located in head and neck area, with scalp the most affected site. This type of melanoma develops on blue naevus or resembles blue naevus, most frequently cellular blue naevus. We present the case of a 52 years old female diagnosed with a pigmented melanoma of the scalp, with maximum tumoral thickness of $6.8 \mathrm{~mm}$ and invasion of the hypodermis, highly resembling cellular blue naevus. All criteria of malignancy were present: prominent nuclear pleomorphism, infiltrative pattern, tumoral necrosis, high mitotic rate $\left(11\right.$ mitoses $\left./ \mathrm{mm}^{2}\right)$ with atypical mitosis and high Ki67 index. No lymph node or distant metastases were identified at presentation.

Because of the rarity of cases, histopathological diagnosis can be difficult, differential diagnosis with blue naevi, atypical blue naevi or metastatic melanoma being the most challenging problems. Prognosis is given by tumoral thickness, frequently being more than $4 \mathrm{~mm}$.

Key words: melanoma, blue naevus.

Blue naevus is a relatively common lesion of the skin; however, the malignant counterpart variant of this lesion is very uncommon. Melanoma arising from blue naevus is an exceedingly rare variant of melanoma, also called "malignant blue naevus" or "blue naevus-like melanoma" $[1,2]$. Most of the cases are located in the head and neck area (scalp $-33 \%$, orbit and face $-32 \%$ ). Trunk mostly back and buttocks (19\%), extremities (7\%) and hands or feet $(7 \%)$ are in decreasing order of frequency the other sites affected [1]. The mean age at diagnosis is 44 years [1]. Slightly more numerous females than males were diagnosed $[1,3]$. Other study found more lesions in men and with trunk localization [2]. This type of melanoma develops on blue naevus or resembles blue naevus, most frequently cellular blue naevus [1]. Because of the rarity of cases, histopathological diagnosis can be difficult.
We present the case of a 52 years old female diagnosed with a pigmented melanoma of the scalp, consisting with melanoma arising from blue naevus.

\section{CASE REPORT}

The patient, a 52 years old female, presented in the Department of Surgery of "Colentina" University Hospital for a large tumor on the scalp area. The tumor measured 1.5/1.2/0.7 cm, bluebrown nonuniform colored, firm, nodular, asymmetrical, without ulceration. The microscopic examination revealed the presence of a malignant proliferation of epithelioid large cells arranged in islands and nests forming lobules in the center of the lesion. At the periphery, the distribution was in 
fascicules, with some spindle cells. In some area an infiltrative pattern was observed. The tumor cells presented abundant eosinophilic or amphophilic cytoplasm, vesicular and moderately pleomorphic nuclei with prominent nucleoli and frequent mitoses (mitotic index $=11$ mitoses $/ \mathrm{mm}^{2}$ ) with atypical forms. Focal accumulation of brown-black pigment (melanin) was present. The tumor has no epidermal involvement and invades the profound dermis and subcutis. The maximum tumor thickness was $6.8 \mathrm{~mm}$. A central, relatively large area of tumoral necrosis was present. At the periphery of the tumoral proliferation minimum perivascular lymphocytic infiltration was noticed. Some perivascular and perineural invasions were seen. No perineural invasion, ulceration, vascular emboli, satellites or in transit metastases were noticed. Immunohistochemical markers performed revealed that tumor cells were positive for $\mathrm{S} 100$ protein, HMB45, Melan A, Tyrosinase (T311), Mitf, E-Cadherin, MMP2, MMP3, MMP9, MMP11, MMP13, TIMP1, TIMP2 and TIMP3. Ki 67 index were $\sim 10 \%$ and focally $25 \%$. Some tumor nuclei were positive for Cyclin D1 and p21 ( 10\%). The nuclear positivity for $\mathrm{p} 53$ was faint. $\beta$ Catenin presented only membrane staining, without nuclear positivity. The tumor cells were negative for AE1AE3, p16, EMA, CK 8/18 and MMP1.

The final diagnosis was melanoma arising from blue naevus, Breslow index $6.8 \mathrm{~mm}$, Clark level $\mathrm{V}$, mitotic index $=11$ mitoses $/ \mathrm{mm}^{2}$, perivascular and perineural invasion - present, no vascular emboli, no ulceration, no tumor infiltrating lymphocytes and no microscopic satellites. The tumor was entirely resected, with a distance to the closer lateral surgical margin of $2.6 \mathrm{~mm}$ and a distance to the closer profound surgical margin of $0.15 \mathrm{~mm}$. TNM pathological classification was pT4a Nx.

Further imagistic investigations were performed and no lymph node or distant metastases were identified. Re-resection with oncological limits have to be evaluated and performed given the fact that the scalp localization of the tumor is relatively difficult to manage.

\section{DISCUSSION}

Melanoma arising from blue naevus is an extremely rare variant of melanoma, in a large USA study represented approximately $0.02 \%$ of melanoma cases [4]. The scalp localization is frequent for this variant of melanoma [1-4]. Clinically and dermatoscopically this type of rare melanoma can resemble nodular melanoma, metastatic melanoma or blue naevus. A benign, blue naevus component can be identified, represented by cellular blue naevus most frequently followed by common blue naevus, naevus of Ota, naevus of Ito and ocular melanocytosis [1]. Clinical examination, dermoscopic examination and reflectance confocal microscopy of blue naevi are difficult because of the variability of aspects, because the symptoms of malignant transformation are poor and arise late in the disease [5-9]; moreover, the thickness of the lesion impairs dermoscopic or reflectance confocal microscopic examination. Blue naevi with satellite lesions represent an important clinical challenge in differentiation diagnosis of melanoma $[5,6,10]$. A wide spectrum of dermatoscopic aspects (whitish, scar-like depigmentation, dots, globules, peripheral streaks or vessels) may be observed in blue naevi [9]. In such difficult cases, clinical and dermatoscopic exclusion of diagnosis of malignant melanoma may be impossible, and surgical excision is necessary.

Final diagnosis is established based on histopathological examination of the lesion, incisional or more indicated excisional biopsy being performed.

Microscopic examination revealed in many cases a benign blue naevus component, easily identified, [11-13] with a component of malignant transformation. It must be differentiated from malignant melanoma associated with blue naevus [14]. In such cases the malignant melanoma 
juxtaposed to a benign blue naevus component, usually a cellular blue naevus. It represents an association of two lesions or a collision tumor, not a true malignant transformation of blue naevus. The melanoma component (frequently a superficial spreading melanoma) has an epidermal involvement in this situation, in contrast to the typical absence of this aspect in definition of melanoma arising from blue naevus (or "malignant blue naevus").

In other cases [15-17], such our case, there is a complete transformation of cellular blue naevus. The diagnosis is made by architecture and cytology resemblance with a blue naevus, but with typical presence of aspects of malignancy: nuclear pleomorphism, prominent nucleoli, some infiltrative pattern, tumoral necrosis, high mitotic rate with atypical mitosis and high Ki67 index. Perivascular lymphocytic infiltration and infiltrative growth pattern are also clues in diagnosis of malignancy in blue melanocytic lesions. In our case architecture and cytology resemble cellular blue naevus in the center of the lesion and common blue naevus at the perifery.

The most important differential diagnosis is the more common melanocytic lesion of cellular blue naevus. Because necrosis is quite specific for malignancy, but rare in this variant of melanoma, the most important criteria of malignancy are represented by nuclear pleomorphism, prominent nucleoli, high mitotic rate with presence of atypical mitosis and high Ki67 index. Intermediate cases (without all the criteria necessary for diagnosis of melanoma) between melanomas arising from blue naevus and cellular benign blue naevi are represented by a gray category of tumors called atypical cellular blue nevi or cellular blue nevi with atypical features [18, 19]. An important study [18] indicates that there is substantial confusion and disagreement among experienced histopathologists about the definitions and biologic nature of cellular blue melanocytic neoplasms particularly those thought to have atypical features ("atypical" cellular blue naevi). In some of these borderline cases, a definitive diagnosis of malignant melanoma can be made only after a follow-up for several years [18].

A cutaneous metastasis with prominent epidermal sparing can mimic a melanoma arising from blue naevus [20]. A careful and complete examination of the skin for a possible primary malignant melanoma must be performed to exclude a metastasis.

Other melanocytic lesions in the differential diagnosis, much more rare than cellular blue naevi or metastatic melanoma, include neurocristic cutaneous hamartoma [21, 22], neurocutaneous melanosis [21], paraganglioma-like dermal melanocytic tumor [23], animal type melanoma or pigmented epithelioid melanocytoma [1, 24]. Melanin pigmentation in our case was focally present compared to heavy pigmentation in animal type melanoma.

Immunohistochemical analyses revealed a typical expression for $\mathrm{S} 100$ protein, HMB45, Melan A, Tyrosinase (T311) and Mitf and a typical negativity for p53, $\beta$ Catenin, AE1-AE3, EMA and CK 8/18. The loss of expression of p16 seems to be suggestive for melanoma in blue melanocytic lesions [25]. The high ki 67 index ( 10\% and focally $25 \%$ in our case) is the most important immunohistochemical marker [1] in diagnosis of malignant melanocytic blue lesions. The expression of p21 and cyclin D1 was low and insignificant.

Immunohistochemical evaluation of changes in the extracellular matrix represented by tissue inhibitor of metalloproteinase (TIMP), matrix metalloproteinase (MMP) and e-cadherin is not specific, with a loss of expression of MMP1 compared with preserved expression of E-Cadherin, MMP2, MMP3, MMP9, MMP11, MMP13, TIMP1, TIMP2 and TIMP3.

Presence of the positivity (membranar) for c-kit in this case can be used, as in other types of malignant melanoma, in prognosis (favorable prognostic with improved outcome in recurrence and metastases) and in treatment with imatinib [26, $27,28]$. 
Molecular analysis with fluorescence in situ hybridization (FISH) targeting commonly altered chromosomal loci in melanoma and comparative genomic hybridization (CGH) can be used in selected cases to distinguish between malignant and benign blue melanocytic tumors [29, 30, 31].

Further imagistic investigations were performed and no lymph node or distant metastases were identified. So, general prognosis and treatment of this case is similar to a malignant melanoma in stage IIC (pT4b N0 M0) [4, 32].

Re-resection in the department of plastic surgery with oncological margins has to be evaluated and performed, given the fact that the scalp localization and the size of the tumor are relatively difficult to manage.
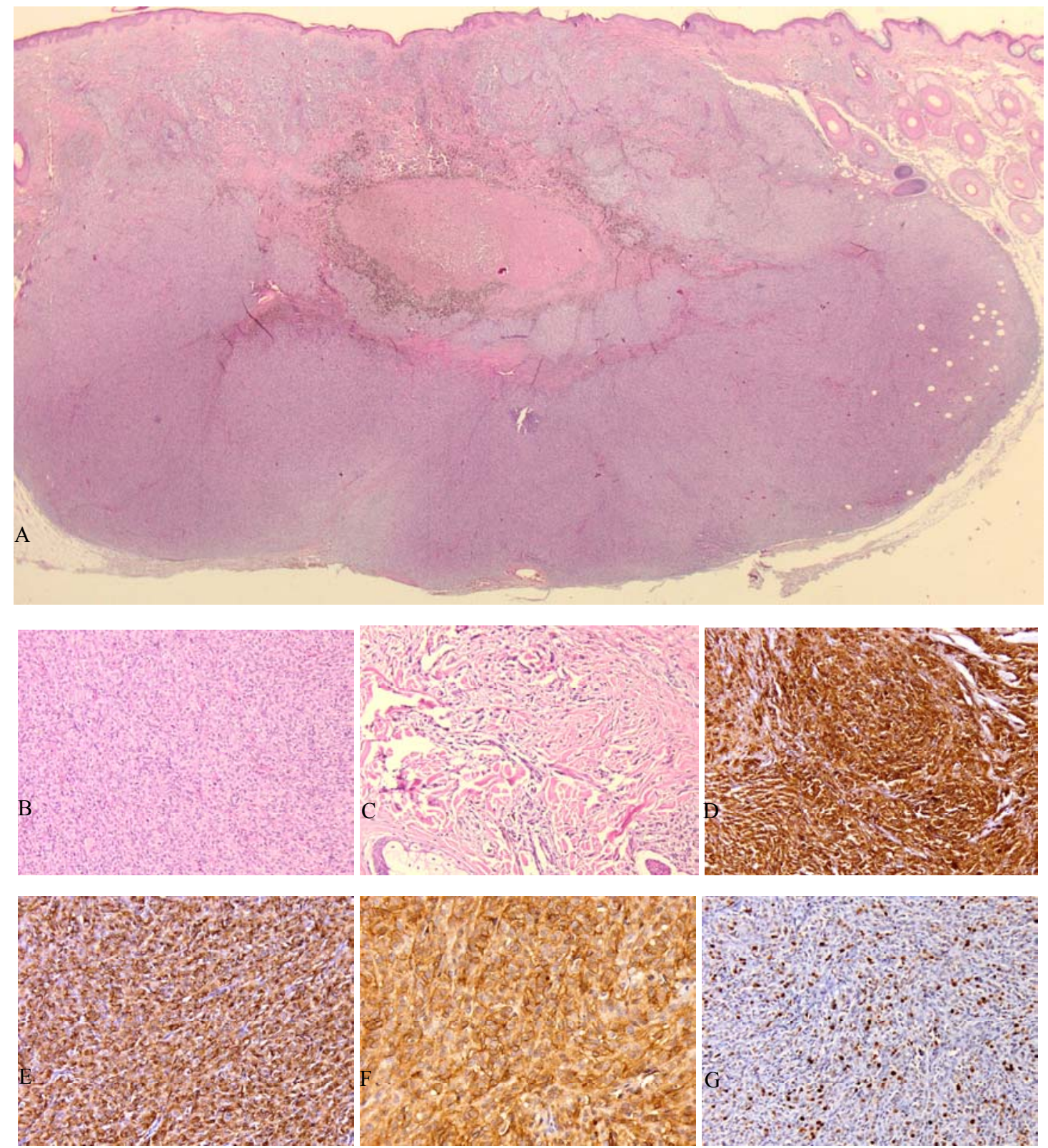

Legend: A. Malignant melanocytic proliferation resembling cellular blue naevus; central area of necrosis. HE $\times 12.5$.

B. Malignant melanocytic proliferation with important cytonuclear pleomorphism resembling cellular blue naevus. HE $\times 200$.

C. Infiltrative pattern in periphery resembling common blue naevus. HE $\times 200$. D. Positivity for S100 protein. S100 $\times 200$.

E. Positivity for HMB45 protein. HMB45 × 200. F. Positivity for c-kit (membrane). C-kit $\times 400$. G. High Ki67 index. Ki67 × 200 . 
Melanomul dezvoltat din nev albastru este o variantă extrem de rară de melanom. Majoritatea cazurilor prezintă localizare la nivelul zonei cap şi gât, scalpul fiind cel mai afectat. Acest tip de melanom se dezvoltă pe nev albastru sau se aseamănă cu un nev albastru, cel mai frecvent, nev albastru celular. Prezentăm cazul unei femei de 52 de ani diagnosticate cu un melanom pigmentat al scalpului, cu grosime tumorală maximă de $6,8 \mathrm{~mm}$ şi invazie în hipoderm, foarte asemănător cu un nev albastru celular. Toate criteriile de malignitate au fost prezente: pleomorfism nuclear, pattern infiltrativ, necroză tumorală, indice mitotic crescut (11 mitoze $/ \mathrm{mm}^{2}$ ) cu forme atipice şi index Ki67 crescut. La prezentare nu au fost identificate metastaze limfoganglionare sau la distanță.

Din cauza rarității cazurilor, diagnosticul histopatologic poate fi dificil, diagnosticul diferențial cu nevi albaştri, nevi albaştri atipici sau metastaze din melanom malign reprezentând cele mai dificile probleme. Prognosticul este dat de grosimea tumorală, frecvent peste $4 \mathrm{~mm}$.

Corresponding author: Sabina Zurac, “Colentina” University Hospital, Department of Pathology,

21, Ştefan cel Mare str, sector 2, 020125, Bucharest, Romania,

Tel +40213173245, Fax +40213165512

E-mail: sabina_zurac@yahoo.com

\section{REFERENCES}

1. L. REQUENA, JA CARLSON. Melanoma arising from blue naevus. World Health Organization Classification of Tumours Pathology and Genetics of Skin Tumours, IARC Press, Lyon, 2006, 79-82.

2. MARTIN RC, MURALI R, SCOLYER RA, FITZGERALD P, COLMAN MH, THOMPSON JF. So-called "malignant blue nevus": A clinicopathologic study of 23 patients. Cancer. 2009 Jul 1; 115(13):2949-55.

3. LOGHAVI S, CURRY JL, TORRES-CABALA CA, IVAN D, PATEL KP, MEHROTRA M, BASSETT R, PRIETO VG, TETZLAFF MT. Melanoma arising in association with blue nevus: A clinical and pathologic study of 24 cases and comprehensive review of the literature. Mod Pathol. 2014 Nov; 27(11):1468-78.

4. KACHARE SD, AGLE SC, ENGLERT ZP, ZERVOS EE, VOHRA NA, WONG JH, FITZGERALD TL. Malignant blue nevus: clinicopathologically similar to melanoma. Am Surg. 2013 Jul; 79(7):651-6.

5. SIHAM LOURARI, LAURENCE LAMANT, ROLAND VIRABEN, CARLE PAUL, NICOLAS MEYER Photoletter to the editor: Blue nevus with satellitosis mimicking melanoma. Contribution of dermoscopy and reflectance confocal microscopy. J Dermatol Case Rep. 2012 June 30; 6(2): 54-56.

6. YONEI N, KIMURA A, FURUKAWA F. Common blue nevus with satellite lesions needs a differential diagnosis from malignant melanoma. Case Rep Dermatol. 2013 Sep 5; 5(3):244-7.

7. HOOS A, BERHO M, BLUMENCRANZ PW, BRADY MS. Giant cellular blue nevus of the anterior chest wall mimicking metastatic melanoma to the breast: A case report. J Surg Oncol. 2000 Aug; 74(4):278-81.

8. CARRERA C, FERRER B, MASCARÓ JM JR, PALOU J. Compound blue naevus: A potential simulator of melanoma. Br J Dermatol. 2006 Jul; 155(1):207-8.

9. DI CESARE A, SERA F, GULIA A, et al. The spectrum of dermatoscopic patterns in blue nevi. J Am Acad Dermatol. 2012; 67:199-205. 
10. OLIVEIRA A, ARZBERGER E, MASSONE C, ZALAUDEK I, FINK-PUCHES R, HOFMANN-WELLENHOF R. Melanoma and satellite blue papule. Dermatol Pract Concept. 2014 Jul 31; 4(3):63-6.

11. SANADA S, HIGAKI K, TORII Y, HIGASHI T, YAMAGUCHI R, NAKAMURA Y, YANO H. Malignant melanoma arising in a plaque-type blue nevus. Pathol Int. 2012 Nov; 62(11):749-53.

12. YEH I, FANG Y, BUSAM KJ. Melanoma arising in a large plaque-type blue nevus with subcutaneous cellular nodules. Am J Surg Pathol. 2012 Aug; 36(8):1258-63.

13. LÖFFLER KU, WITSCHEL H. Primary malignant melanoma of the orbit arising in a cellular blue naevus. Br J Ophthalmol. 1989 May; 73(5):388-93.

14. MELLONE P, BIANCHI A, DRAGONETTI E, MURACE R, PERSICHETTI P, BALDI A. Malignant melanoma associated with a blue naevus: A case report. Cases J. 2008 Dec 31; 1(1):433. doi: 10.1186/1757-1626-1-433.

15. NORTH JP, YEH I, MCCALMONT TH, LEBOIT PE. Melanoma ex blue nevus: Two cases resembling large plaque-type blue nevus with subcutaneous cellular nodules. J Cutan Pathol. 2012 Dec; 39(12):1094-9.

16. BIRCH-JOHANSEN FH, SJØSTRAND H, LOCK-ANDERSEN J. Malignant melanoma in association with or mimicking blue naevus. Scand J Plast Reconstr Surg Hand Surg. 2010 Apr; 44(2):118-20.

17. MICHAL M. Cellular blue naevi with microalveolar pattern - a type of naevus frequently confused with melanoma. Pathol Res Pract. 1998; 194(2):83-6.

18. BARNHILL RL, ARGENYI Z, BERWICK M, DURAY PH, ERICKSON L, GUITART J, HORENSTEIN MG, LOWE L, MESSINA J, PAINE S, PIEPKORN MW, PRIETO V, RABKIN MS, SCHMIDT B, SELIM A, SHEA CR, TROTTER MJ. Atypical cellular blue nevi (cellular blue nevi with atypical features): lack of consensus for diagnosis and distinction from cellular blue nevi and malignant melanoma ("malignant blue nevus"). Am J Surg Pathol. 2008 Jan; 32(1):36-44.

19. TRAN TA, CARLSON JA, BASACA PC, MIHM MC. Cellular blue nevus with atypia (atypical cellular blue nevus): A clinicopathologic study of nine cases. J Cutan Pathol. 1998 May; 25(5):252-8.

20. BUSAM KJ. Metastatic melanoma to the skin simulating blue nevus. Am J Surg Pathol. 1999 Mar; 23(3):276-82.

21. GARCÍA-RABASCO A, MARÍN-BERTOLÍN S, ESTEVE-MARTÍNEZ A, ALEGRE-DE-MIQUEL V. Dermal melanocytosis of the scalp associated to intracranial melanoma: malignant blue nevus, neurocutaneous melanosis, or neurocristic cutaneous hamartoma? Am J Dermatopathol. 2012 Apr; 34(2):177-81.

22. LINSKEY KR, DIAS-SANTAGATA D, NAZARIAN RM, LE LP, LAM Q, BELLUCCI KS, ROBINSON-BOSTOM L, MIHM MC JR, HOANG MP. Malignant neurocristic hamartoma: A tumor distinct from conventional melanoma and malignant blue nevus. Am J Surg Pathol. 2011 Oct; 35(10):1570-7.

23. DEYRUP AT, ALTHOF P, ZHOU M, MORGAN M, SOLOMON AR, BRIDGE JA, WEISS SW. Paraganglioma-like dermal melanocytic tumor: A unique entity distinct from cellular blue nevus, clear cell sarcoma, and cutaneous melanoma. Am J Surg Pathol. 2004 Dec; 28(12):1579-86.

24. ZEMBOWICZ A, CARNEY JA, MIHM MC. Pigmented epithelioid melanocytoma: A low-grade melanocytic tumor with metastatic potential indistinguishable from animal-type melanoma and epithelioid blue nevus. Am J Surg Pathol. 2004 Jan; 28(1):31-40.

25. CHANG LM, CASSARINO DS. p16 expression is lost in severely atypical cellular blue nevi and melanoma compared to conventional, mildly, and moderately atypical cellular blue nevi. ISRN Dermatol. 2014 Jan 22; 2014:348-417.

26. BERROCAL A, CABAÑAS L, ESPINOSA E, FERNÁNDEZ-DE-MISA R, MARTÍN-ALGARRA S, MARTÍNEZ-CEDRES JC, RÍOS-BUCETA L, RODRÍGUEZ-PERALTO JL. Melanoma: diagnosis, staging, and treatment. Consensus group recommendations. Adv Ther. 2014 Sep; 31(9):945-60.

27. KARIMKHANI C, GONZALEZ R, DELLAVALLE RP. A review of novel therapies for melanoma. Am J Clin Dermatol. 2014 Aug; 15(4):323-37. 
28. MOHAMED A, GONZALEZ RS, LAWSON D, WANG J, COHEN C. Tumor stem cells (CD271, c-kit, SOX10) in Melanomas: prognostic and outcome implications. Appl Immunohistochem Mol Morphol. 2014; 22(2):142-5.

29. GAMMON B, BEILFUSS B, GUITART J, BUSAM KJ, GERAMI P. Fluorescence in situ hybridization for distinguishing cellular blue nevi from blue nevus-like melanoma. J Cutan Pathol. 2011 Apr; 38(4):335-41.

30. GERAMI P, POURYAZDANPARAST P, VEMULA S, BASTIAN BC. Molecular analysis of a case of nevus of ota showing progressive evolution to melanoma with intermediate stages resembling cellular blue nevus. Am J Dermatopathol. 2010 May; 32(3):301-5.

31. POURYAZDANPARAST P, NEWMAN M, MAFEE M, HAGHIGHAT Z, GUITART J, GERAMI P. Distinguishing epithelioid blue nevus from blue nevus-like cutaneous melanoma metastasis using fluorescence in situ hybridization. Am J Surg Pathol. 2009 Sep; 33(9):1396-400.

32. BIRCH-JOHANSEN FH, SJØSTRAND H, LOCK-ANDERSEN J. Malignant melanoma in association with or mimicking blue naevus. Scand J Plast Reconstr Surg Hand Surg. 2010 Apr; 44(2):118-20.

Received January 20, 2015 